\title{
THE RIGHT TO PUNISHMENT FOR INTERNATIONAL CRIMES
}

\author{
Jens David Ohlin*
}

On October 1, 2002, Magnus Gäfgen was taken into custody by the Frankfurt police in connection with the kidnapping of a young boy held for ransom. ${ }^{1}$ What happened next is well known both to the German public and to international lawyers interested in criminal law. The police threatened Gäfgen with various forms of torture (including a reference to sexual assault) unless he divulged the location of the boy. Gäfgen quickly relented and led the police to the boy, who was already dead. Gäfgen was convicted of murder and the police were convicted of coercion. However, the district court in Frankfurt concluded that the police, though culpable, were not appropriate subjects of punishment, and therefore sentenced them to small monetary fines, which were then suspended. ${ }^{2}$ Essentially, the police escaped serious consequences for their behavior.

This is where the story gets really interesting. Gäfgen, unhappy that his torturers were not punished, filed a case against Germany at the European Court of Human Rights (ECHR). ${ }^{3}$ Gäfgen argued that Germany's failure to punish his torturers violated his human rights as protected by the European Convention on Human Rights. ${ }^{4}$ The ECHR concluded that Gäfgen was rightthe German government was obligated to punish perpetrators of torture, and by failing to do so adequately, Germany violated Gäfgen's human rights.

Although the ECHR's Gäfgen v. Germany decision received widespread attention, I do not believe that international criminal lawyers fully digested its implications. ${ }^{5}$ In this chapter, I hope to demonstrate the significance of Gäfgen, as well as the prior ECHR cases it relied upon, and show that it points the way towards a general theory of a state's responsibility to punish. This human-

*Vice Dean and Professor of Law, Cornell Law School.

${ }^{1}$ Case of Gäfgen v. Germany, European Court of Human Rights, Grand Chamber, Application No. 22978/05 (1 June 2010), para. 14.

2 See Landgericht Frankfurt a.M., Judgment of 20 December 2004, Neue Juristische Wochenschrift2005, 692-696.

${ }^{3}$ See Gäfgen (n 1) para. 2.

${ }^{4} \mathrm{Id}$. at para. 75 .

${ }^{5}$ A notable exception is the excellent article by Florian Jeßberger, 'Bad Torture-Good Torture? What International Criminal Lawyers May Learn from the Recent Trial of Police Officers in Germany', 3 Journal of International Criminal Justice 1059-1073 (2005). 


\section{The Right to Punishment}

rights approach is significant for several reasons. First, theorists of punishment are usually in the business of constructing justifications for punishment, that is, an argument in favor of coercive state action if the state elects to exercise that power. But the Gäfgen approach focuses almost exclusively on the state's duty to punish. Second, and relatedly, if the state forgoes its option to punish, theorists have often viewed such exercises of "mercy" as normatively desirable events. ${ }^{6}$ However, the Gäfgen approach suggests that such moments of mercy may, in some circumstances, be problematic from the perspective of international human rights law. Third, the legal foundation for the obligation stems not from an obligation owed to the entire community but rather an obligation owed to the victims. Fourth, and finally, human rights activists and lawyers are more used to discussing human rights in the context of constraints on punishment. ${ }^{7}$ In this case, however, the notion of human rights is being deployed in favor of punishment as an absolute requirement of a system of law that respects human rights. Instead of the defense appealing to human rights in arguing for the forbearance of punishment; we now have the prospect of the prosecution appealing to human rights in arguing for the necessity of punishment.

It would be useful, therefore, to connect these nascent developments in human rights theory to the literature on human rights in international criminal law. There is already a rich literature on punishment written by international criminal lawyers, often canvassing the important debates between retributivism, deterrence, and expressivism. ${ }^{8}$ There is also a growing literature

${ }^{6}$ See, for example, Jeffrie G. Murphy, 'Forgiveness, mercy, and the retributive emotions', 7 Criminal Justice Ethics 3-15 (1988); Carla Ann Hage Johnson, 'Entitled to clemency: Mercy in the criminal law', 10 Law and Philosophy 109-118 (1991). But see Stephen P. Garvey, 'Is It Wrong to Commute Death Row? Retribution, Atonement, and Mercy', 82 N.C. L. Rev. 1319, 1334 (2004) ('Keep in mind that the imperfect obligation to show mercy always competes with the perfect obligation to achieve retributive justice. As such, with every act of mercy comes a corresponding denial of justice. At some point, so it would seem, the demands of justice must prevail against those of mercy.'); R.A. Duff, 'The Intrusion of Mercy', 4 Ohio St. J. Crim. L. 361, 381 (2007) ('I have argued so far that mercy does have a proper, although limited, role in the context of criminal law and punishment, but that that role cannot be captured or explained within the perspective of criminal or penal justice: seen from within that perspective, mercy must appear as something arbitrary or unreasonable (since it is not grounded in what can count as relevant reasons from that perspective). Mercy marks, not an application of penal justice, but rather an intrusion into the sphere of penal justice by moral values and concerns that are not matters of justice.').

${ }^{7}$ See, e.g., William A. Schabas, The Abolition of the Death Penalty in International Law (3d ed. 2002).

${ }^{8}$ For a good discussion, see Mark A. Drumbl, Atrocity, Punishment, and International Law (2007). 
on the role that human rights law can and should play in international criminal law, especially in the context of international criminal procedure. ${ }^{9}$ Finally, there also is a foundational enterprise of appealing to the anti-impunity norm as a basic grundnorm of international criminal law. ${ }^{10}$ These various strands should be pulled together to create a human rights-centric theory of punishment. At its heart, the theory will do nothing less than demonstrate that mercy is, in fact, not morally desirable, but in fact legally unconscionable-a human rights violation. If this argument is true, it has wide implications for both the theory and practice of international criminal law, as well as domestic law. For indeed, there are a wide variety of places where the state exercises mercy: suspended sentences, pardons, commutations, supervised released programs, etc. In each of these cases, however, the sovereign "grace" expressed by acts of mercy may violate the human rights of the victims. Or, at the very least, grants of excessive mercy may violate this right.

The goal of this chapter is to show that the argument in Gäfgen is generalizable to other contexts. Although the case arose from a particular procedural posture - a violation, by police officers, of the prohibition against torture-there is little reason to suspect that the arguments in Gäfgen will not hold for other crimes as well. At the very least, these arguments can be extended, without logical disruption, to other international crimes that states are under a legal obligation to criminalize, such as war crimes, crimes against humanity, and genocide. Moreover, if the structure of these arguments is conceptually sound, in theory they should apply outside of the European context, unless the argument is based on a particular right that is only protected by the ECHR and not by international law. Also, if these arguments are sound, they should also apply when international tribunals are prosecuting these crimes, even though international tribunals are not directly bound by international human rights obligations, although almost every international tribunal recognizes that its decisions should remain faithful to international human rights

${ }^{9}$ See Goran Sluiter et al, International Criminal Procedure: Principles and Rules 81 (2013) ('There is no reason to doubt that customary norms on human rights apply to international organizations.').

${ }^{10}$ Compare Jamie Mayerfeld, 'Ruthlessness, Impunity, and the Effacement of International Human Rights Law', 8 Santa Clara J. Int'l L. 289, 293 (2010) with Karen Engle, 'Anti-Impunity and the Turn to Criminal Law in Human Rights', 100 Cornell L. Rev. 1069, 1119 (2015) ('Yet, the fight against the culture of impunity-with impunity narrowly defined as foreclosing the option of criminal punishment-has not only taken up a significant amount of the human rights movement's space; it has helped shape the direction of human rights advocacy as well as both international human rights and international criminal law.'). 
law. ${ }^{11}$ Finally, it should make no difference whether the object of prosecution is a state agent, as it was in Gäfgen, or whether it is a private actor found guilty of committing another international crime. What matters is the status of the victim, not the status of the perpetrator.

The conclusion may be hard to swallow and may sound counter-intuitive. The idea that mercy is a human rights violation goes against the rich tradition of human rights advocacy. One might argue that the Gäfgen case got it wrong, or that the ECHR long ago took a wrong turn in overseeing punishments handed down in domestic criminal cases. But I hope to demonstrate that Gäfgen is not wrongly decided. Moreover, I hope to demonstrate that if we take the reasoning in Gäfgen seriously, it requires that we recognize that victims of international crimes have a legal right to see their perpetrators punished. Moreover, not only cases of zero punishment but also cases of inadequate punishment constitute a violation of that human right. It is in this sense that we may legitimately talk of a "right to punishment" under human rights law. ${ }^{12}$

\section{The FACTS OF THE CASE}

Although the facts of Gäfgen's case are well known, it is important to revisit them to determine whether the reasoning in the ECHR's decision is sui generis - that is, intimately and inextricably tied to the facts of the case-or whether it is generalizable to other international crimes.

When Gäfgen was brought into police custody for questioning, his victim was already dead. According to the police and the prosecutors, Gäfgen killed the boy first and only then attempted to extract a ransom from the boy's family by pretending that the boy was still alive. ${ }^{13}$ However, when the police started their interrogation, they were ignorant of this fact. The police lieutenant in charge of the detective unit, Lieutenant Daschner, ordered detectives under his command to threaten Gäfgen to get him to divulge the location of the

${ }^{11}$ For example, see Prosecutor v. Slobodan Milosevic, Reasons for Decision on Assignment of Defence Counsel, ICTY Trial Chamber, 22 September 2004, para. 29 (citing and applying procedural protections recognized in human rights treaties).

${ }^{12}$ My use of the phrase "right to punishment" should be distinguished from the Kantian use of that phrase, which suggests that offenders have a right to punishment because all offenders have a "right" to be treated as a moral agent. See Herbert Morris, On Guilt and Innocence: Essays in Legal Philosophy and Moral Psychology 41 (1976); Russell L. Christopher, 'The Prosecutor's Dilemma: Bargains and Punishments', 72 Fordham L. Rev. 93, 128 (2003). This is not the sense in which I use the phrase. When I refer to the "right to punishment," I refer to the remedial right of victims to see their victimizers punished.

${ }^{13}$ See Gäfgen (n 1) para. 11-12. 
kidnapped boy. ${ }^{14}$ On Daschner's orders, the detectives told Gäfgen that he would be placed in a cell with several individuals who would anally rape him. The detectives also told him that a police specialist was arriving who had instruments capable of producing intolerable levels of pain without causing permanent injury. ${ }^{15}$ The point of this last threat seemed to suggest that the police were unafraid of the consequences of torturing Gäfgen because they could do so with impunity; the lack of physical injuries would entail that no one would believe Gäfgen. Finally, the police detectives also planned to administer a truth serum that would force Gäfgen to divulge the information. ${ }^{16}$ (It is unclear if this latter plan was communicated to Gäfgen as a threat; if yes, the threat to Gäfgen would suggest to him that there was no reason to endure the torture, since they would get the information anyway, thus encouraging him to divulge the information.)

Gäfgen quickly divulged the location of the boy and the police took him to the field where he walked-apparently barefoot-to the general location of the body. ${ }^{17}$ Gäfgen was then charged with murder. Toward the end of his trial, Gäfgen gave a statement to the court where he conceded that he murdered the boy, saying that confession was "the only way to accept his deep guilt" and express "the greatest possible apology for the murder of the child." 18

Gäfgen argued that because his treatment was improper, and violated his basic dignity under article 1 of Germany's Basic Law (GG), he was owed an extraordinary remedy: the dismissal of all charges and his eventual release. ${ }^{19}$ The German courts decided on a more limited remedy: Gäfgen's statement regarding the boy's location was excluded from the trial because it was the product of his mistreatment, but the court allowed the introduction of downstream evidence that the police gathered (the fruit of the poisonous tree), including the forensics evidence from the boy's body. ${ }^{20}$ Moreover, Gäfgen's testimony at trial provided an alternative confession that established his guilt even though the original statement was not admissible. The ECHR confirmed this finding and refused to agree with Gäfgen that his mistreatment required dismissal of the charges against him. ${ }^{21}$

${ }^{14} I d$. at para. 15.

${ }^{15} \mathrm{Id}$. at para. 15.

${ }^{16} \mathrm{Id}$. at para. 20.

${ }^{17} \mathrm{Id}$.

${ }^{18} \mathrm{Id}$. at para. 32.

${ }^{19} \mathrm{Id}$. at para. 24.

${ }^{20} \mathrm{Id}$. at para. 27.

${ }^{21} \mathrm{Id}$. at para. 179. 
However, Gäfgen was successful in convincing the ECHR that the German courts had erred in their treatment of Daschner and the police detectives who carried out the torture scheme. Daschner made no attempt to hide his involvement and drafted a memo to the official file the day after the interrogation that explained and justified his actions. ${ }^{22}$ Following an investigation, Daschner and the other detectives were criminally charged and found guilty of criminal coercion or incitement to coercion for their mistreatment of Gäfgen. ${ }^{23}$ The court concluded that Daschner was not entitled to the defense of justified necessity nor the defense of excused necessity, for a variety of reasons. ${ }^{24}$ First, the boy he sought to save was not a close family relation. Second, the use of torture was not an "appropriate" means to resolve the emergency because it violated Gäfgen's inviolable human dignity protected by article 1 of the Basic Law. ${ }^{25}$

However, despite the Frankfurt court's refusal to exonerate Daschner and the other police detectives, the court refused to punish Daschner. In so doing, the court effectively created a new ad hoc category falling somewhere in the hinterland between culpable and non-culpable. Daschner was culpable but not an appropriate subject of punishment-a consequence that criminal lawyers typically attach to a finding of no culpability. In so doing, the court created three boxes where in the past there had been two. Defendants are either culpable and subject to punishment, culpable and not subject to punishment, or non-culpable and not subject to punishment. Daschner fit into the second box.

Gäfgen was not as impressed with the trial court's creativity as legal scholars were. Gäfgen argued before the ECHR that the Frankfurt court's failure to punish Daschner had violated Gäfgen's human rights. Indeed, Germany's position was somewhat precarious. If its domestic courts had concluded that Daschner was not guilty because he was protected by either excused or justified necessity under the German criminal code, then that would have been a different matter. However, the Frankfurt court explicitly conceded that Daschner was guilty enough to be convicted, just not guilty enough to be punished. It was precisely this conceptual move that allegedly violated Gäfgen's human rights. His human rights having been violated, it was imperative that the state punish the perpetrators; their failure to do so violated human rights law. ${ }^{26}$

${ }^{22}$ Id. at para. 20.

${ }^{23}$ Id. at para. 49.

${ }^{24}$ Id. at para. 48 . The trial court's application of the necessity defense is analyzed in Jeßberger (n 5) 1064.

25 Jeßberger (n 5) 1065.

${ }^{26}$ See Gäfgen (n 1) para. 124. 


\section{THE GRAND CHAMBER OPINION}

As noted above, the ECHR's Grand Chamber concluded that Gäfgen's human rights were violated when Germany declined to punish his torturers. The opinion includes several moving parts. The goal of this section is to break down the essential parts and then, in the following section, to see if the legal argument can be generalized and extended beyond the torture context.

Germany violated Gäfgen's rights under article 3 of the European Convention, which states that "[n]o one shall be subjected to torture or to inhuman or degrading treatment or punishment," a requirement that is also codified in the Convention Against Torture. ${ }^{27}$ According to the ECHR's existing jurisprudence, implicit in this prohibition is the requirement that a victim have adequate access to avenues of redress. This is both a procedural norm and an outcome requirement-including government compensation and punishment of offenders. This view of Convention rights is created by reading article 3 in conjunction with article 1 , the jurisdictional provision of the Convention, which requires that states "shall secure to everyone within their jurisdiction the rights and freedoms defined in Section I of this Convention." ${ }^{28}$ So the duty to punish comes from the interplay between the prohibition against torture and the positive obligation to secure the rights of the Convention to all who are protected to it. As the ECHR has observed, "under Article 19 of the Convention and in accordance with the principle that the Convention is intended to guarantee rights that are not theoretical or illusory, but practical and effective, the Court has to ensure that a State's obligation to protect the rights of those under its jurisdiction is adequately discharged." 29

The ECHR therefore scrutinized, as it has in many cases before, whether Germany's investigation of the complainant's mistreatment by state officials was adequate and effective-ultimately finding that it was adequate. ${ }^{30}$ However, the state's failure to adequately punish Daschner and his colleagues was not acceptable. According to the ECHR, the court felt a legal obligation to review the domestic application of criminal penalties in this case:

${ }^{27}$ Convention for the Protection of Human Rights and Fundamental Freedoms (European Convention on Human Rights), art. 3, opened for signature 1950, entered into force 1953.

${ }^{28}$ European Convention on Human Rights, art. 1.

${ }^{29}$ See Gäfgen (n 1) para. 123.

${ }^{30} \mathrm{Id}$. at para. 4. 
Nevertheless, imposing almost token fines of 60 and 90 daily payments of EUR 60 and EUR 120 respectively, and, furthermore, opting to suspend them, cannot be considered an adequate response to a breach of Article 3, even seen in the context of the sentencing practice in the respondent State. Such punishment, which is manifestly disproportionate to a breach of one of the core rights of the Convention, does not have the necessary deterrent effect in order to prevent further violations of the prohibition of ill-treatment in future difficult situations. ${ }^{31}$

What is interesting about this conclusion is that it appears to combine both retributive and deterrent rationales for concluding that the punishment was inappropriately lenient. The token fines, which were not even imposed, were "manifestly disproportionate," a point that the Grand Chamber later elaborated on when it referred to the "manifest disproportion between the gravity of the act and the punishment imposed." 32 This suggests a retributive calculation because the punishment must be proportional to the "gravity" of the act, rather than proportional to a particular consequence. At the same time, however, the court also articulated a deterrence rationale, suggesting that the failure to punish would fail to deter future offenders or prevent further violations.

The structure of these two normative duties is quite different. The first, the retributive consideration, is tied directly to the victim's interest-the interest in seeing his perpetrators adequately punished. The second, the deterrence rationale, is by logic not tied directly to the interest of the victim in the case, since whether future offenders are deterred impacts not the past victim but future unspecific victims. It is unclear why failure to deter acts against future victims violates the human rights of the prior victim. For that reason, the retributive rationale seems to be the strongest of the two arguments. Applying the facts of the case to this legal standard, the ECHR also concluded that Germany's failure to hand down appropriate administrative consequences-transferring Daschner to an equivalent post rather than demoting or fire him-was also impermissible. ${ }^{33}$

In scrutinizing the sufficiency (or lack thereof) of Daschner's sentence, the ECHR committed itself to a "supervisory function" of domestic penal sanctions, a role that it wholeheartedly embraced rather than shying away from it. ${ }^{34}$ According to the Grand Chamber, "[i]t follows that while the Court

${ }^{31} \mathrm{Id}$. at para. 124.

32 Id. at para. 123.

${ }^{33} \mathrm{Id}$. at para. 125.

${ }^{34} \mathrm{Id}$. at para. 123. 
acknowledges the role of the national courts in the choice of appropriate sanctions for ill-treatment by State agents, it must retain its supervisory function and intervene in cases of manifest disproportion between the gravity of the act and the punishment imposed." 35 In other words, while trial courts are especially well-suited to determining the appropriateness of specific penal sanctions (having heard the relevant evidence during a trial), trial court decisions are not to be accepted without judicial scrutiny. In cases of "manifest disproportion," it is appropriate for a regional or international tribunal to declare that the inadequate sentence violated the state's obligations under European human rights law. It should be noted, of course, that a finding of "manifest disproportion," as in Gäfgen's case, simply entailed a legal finding and an order of compensation from Germany to the victim; it did not result (because it could not) in a judicial nullification of Daschner's sentence or in a judicial order to the German courts requiring them to re-sentence Daschner consistent with human rights law. Such a result, though theoretically possible, would presumably have violated the requirements of domestic criminal procedure and the rights of the defendant.

It remains to be seen how much of the court's analysis is specific to the crime of torture. Although the decision is, by its terms, tethered to the article 3 prohibition against torture, the real conceptual work is done by article 1 . It would be illogical to suggest that torture is the only human rights prohibition that requires punishment. Indeed, article 1 requires that the state "secure" convention rights to all individuals, and this positive obligation could be logically combined with other convention rights. The most important examples are the article 2 obligation to protect the right to life, the article 4 prohibition on slavery and forced labour, and the article 5 protection of security and liberty. There are others. Each of these legal protections, when combined with article 1 , could and should generate the same duty to punish as found in the context of torture.

Indeed, other ECHR cases have articulated a duty to punish in other contexts. For example, in Ali and Ayşe Duran v. Turkey, the ECHR concluded that there was a human rights violation wherein the government failed to enforce the sentences of police officers who were convicted of ill-treatment of the complainant. ${ }^{36}$ In that case, the government's failure to punish the officers, who were convicted, "demonstrated a clear disproportion between the gravity of the offence in question and the punishment imposed." 37 Incidentally, this conclusion goes even further than Gäfgen, because it suggests that even where

${ }^{35} \mathrm{Id}$.

${ }^{36}$ Ali and Ayşe Duran v. Turkey, European Court of Human Rights, Third Section, Application No. 42942/02, 8 April 2008.

${ }^{37}$ Id. at para. 71. 
punishment is imposed at law (by the judiciary), there might be a human rights violation if the punishment is never brought to fruition by the executive branch.

Similarly, in Özcan and Others v. Turkey, the ECHR concluded that Turkey was responsible for its failure to punish police officers involved in an unlawful killing. In $\ddot{O} z c a n$, however, the alleged mistreatment was not a violation of the article 3 prohibition against torture, but rather a violation of the article 2 right to life:

Concerning the Government's objection to the applicants' victim status based on the issue of compensation the Court reiterates that, in cases concerning deprivations of life, Contracting States have an obligation under Article 2 of the Convention to conduct an effective investigation capable of leading to the identification and punishment of those responsible. That obligation would be rendered illusory if, in respect of complaints under Article 2 of the Convention, an applicant's victim status were to be remedied by merely awarding damages... Confining the authorities' reaction to incidents of deprivations of life to the mere payment of compensation would also make it possible in some cases for agents of the State to abuse the rights of those within their control with virtual impunity, and the general legal prohibitions on killing, despite their fundamental importance, would be ineffective in practice... ${ }^{38}$

So it is clear that the obligation to punish extends beyond cases of torture to all cases involving unlawful killings in violation of the right to life. Since most cases of serious violations of domestic and international criminal law involve an unlawful and arbitrary deprivation of life, one can already see the seeds of a generalized theory of a duty to punish offenders in order to vindicate the rights of victims. The ECHR issued a virtually identical holding in Nikolova and Velichkova. ${ }^{39}$

Moreover, there is no reason to limit the state's obligation to punish to misconduct by public actors. In the famous M.C. v. Bulgaria case, Bulgaria was held responsible for its failure to apply its rape jurisprudence in a way that would provide an adequate remedy for victims of sexual violence. ${ }^{40}$ Specifically,

${ }^{38}$ See $\ddot{O} z$ can and Others $v$. Turkey, European Court of Human Rights, Second Section, Application No. 18893/05, 20 April 2010, para. 54.

${ }^{39}$ See Nikolova and Velichkova v. Bulgaria, European Court of Human Rights, Fifth Section, Application No. 7888/03, 20 December 2007, para. 55.

${ }^{40}$ M.C. v. Bulgaria, European Court of Human Rights, First Section, Application No. 39272/98, 4 December 2003. 
the Bulgarian system had retained allegedly obsolete force and resistance requirements that made it difficult for the police or prosecutor to hold perpetrators responsible for acts that the ECHR concluded constituted rape. In making this determination, the ECHR stated that:

The Court reiterates that the obligation of the High Contracting Parties under Article 1 of the Convention to secure to everyone within their jurisdiction the rights and freedoms defined in the Convention, taken together with Article 3, requires States to take measures designed to ensure that individuals within their jurisdiction are not subjected to ill-treatment, including ill-treatment administered by private individuals. ${ }^{41}$

In this regard, the court's holding in M.C. v. Bulgaria was a reaffirmation of its prior holding in A. $v$. United Kingdom that the duty to punish applies to "illtreatment administered by private individuals" and that "[c]hildren and other vulnerable individuals, in particular, are entitled to State protection, in the form of effective deterrence, against such serious breaches of personal integrity." 42

Taken together, these precedents make it unsurprising that the ECHR in Gäfgen would conclude that Germany had violated the complainant's human rights. The obligation to ensure an effective remedy is a combination of an article 1 "securing" obligation with another human rights protection, including the right to life. Civil compensation by itself is inadequate if the perpetrators do not receive a criminal punishment. More importantly, even the application of a criminal punishment may be inadequate if there is a "manifest disproportion" between the gravity of the crime and the punishment. This requirement is both backward looking in the sense that it must satisfy retributive concerns with regard to that particular victim and forward looking in the sense that it must respond to the interests of future victims. If this process requires international human rights law-as a body of law-to look over the shoulder of the criminal process, then so be it.

${ }^{41}$ Id. at para. 149 .

42 See A. v. United Kingdom, European Court of Human Rights, 23 September 1998, Application No. 25599/94, para. 22. See also $X$ and $Y v$. The Netherlands, European Court of Human Rights, 26 March 1985, paras. 21-27 (concluding that civil law remedies were an insufficient remedy for rape and that only a criminal law remedy, with effective penalties, would secure the victim's rights under the Convention). 


\section{THE GENERALTHEORY}

In the following section, I hope to articulate in conceptual terms a general theory that expresses the state's duty to punish offenders as a requirement of the individual human rights of victims-hence the expression "the right to punishment." Unlike the prior section which articulated this account within the context of existing ECHR jurisprudence, this section will offer an a priori account appealing to first principles. By drawing on shared intuitions of human rights, I hope to demonstrate that even outside of the context of ECHR jurisprudence, victims have a human right to adequate recourse that includes the punishment of their victimizers, and the law should recognize this right. The ultimate goal of this normative account is to show that excessive forms of mercy are not just undesirable in a broad sense but also infringe the rights of individuals. It is not just society that loses something when excessive or inappropriate mercy is conferred on perpetrators; specific individuals are harmed by this process. Criminal lawyers are trained to view punishment as an institutional relationship between the state and the offender who is punished. This section will redraw that portrait as a triangle that connects the state, the perpetrator, and the victim.

The right not to be deprived of life arbitrarily is one of the most fundamental human rights. All individuals, simply by virtue of their human dignity, have a right to life. Closely akin to this right is the right to be secure in their persons and the right to be free from torture and other forms of mistreatment. Taken together and broadly construed, these rights articulate a general prohibition against brutality and the right not to be subject to criminal violence. When an individual is victimized by illegal violence, the crime constitutes both a public and private wrong-a wrong perpetrated against the legal order (the community) and the individual victim.

For the moment, the exact conceptual ground for these rights is irrelevant to the argument, because everyone is in agreement that these rights are universal. One might appeal to the human dignity of all individuals as expressed in Kantian terms, i.e. the fact that each individual is entitled, by virtue of their status as moral agents, to be treated in accordance with universal human legislation. ${ }^{43} \mathrm{Or}$, one might appeal to a neo-Kantian social contract framework, wherein these rights are guaranteed because they would have been selected by bargainers negotiated in the original position behind a veil of ignorance. ${ }^{44} \mathrm{Or}$, the rights are implied by a Republican conception of freedom as

${ }^{43}$ See Universal Declaration of Human Rights, U.N. GAOR, 2 d Special Sess., Supp. No. 2, pmbl., at 72, U.N. Doc. A/810 (1948); Immanuel Kant, Grounding for the Metaphysics of Morals 36-37 (James W. Ellington trans., Hackett 3d ed. 1993) (1785).

${ }^{44}$ See John Rawls, A Theory of Justice 123 (rev. ed. 1999). 
non-denomination. ${ }^{45}$ In other words, all human beings have an inherent right to freedom, and their subjection to violence against their bodily integrity puts them in a state of domination between the perpetrator and the victim-a status of subordination that offends the very essence of human freedom.

Both public and private violence offend this basic right to be free from mistreatment, although the structure of each violation is slightly different. When state officials engage in the violence, the state is in the direct position of violating the rights of its own citizens. In the case of private violence, both the aggressor and the victim are private individuals, and the state is responsible, if at all, insofar as it owes positive obligations to the victim to prevent and punish the violations. In the first scenario, the state is responsible for its commission; in the second scenario, the state is responsible for its omission, that is, its failure to take adequate steps in response to the victimization.

The more contested issue is how to draw the line from the original rights violation to a rights-claim regarding an adequate remedy in the criminal law-the requirement to punish. It is in this area where the ECHR precedents are at their thinnest - all they say is that without a criminal consequence, perpetrators will continue to commit crimes with impunity, and by extension, the rights of the Convention will be merely hypothetical instead of actual. Is there anything more that could be said on this score?

The answer lies not just in the original victimization by the perpetrator but also in a second-order right to live in a community where rights-violations are taken seriously. When a state refuses to punish offenders, it expresses its de facto approval of their conduct in the form of tacit endorsement. At the very least, the failure to punish suggests a form of moral equivocation, that is, it is uncertain how "wrong" the conduct really was. This notion is certainly true in in the case of Gäfgen; the German courts refused to punish Daschner and his officers because they were sympathetic to their plight. The reason for this sympathy was precisely one example of this moral equivocation-a suggestion that their actions were not fully blameworthy, under the circumstances, despite their commission of the criminal offense.

In this vein, the state responsibility towards victims of private wrongs is a communicative obligation - an obligation to adequately express not just the nature of society's disapproval for the human rights violation but also the intensity of that disapproval relative to the gravity of the human rights violation. Failure to express disapproval constitutes tacit endorsement of the rights violation-an endorsement that runs smack into the state's obligations under international human rights law. The obligation is not just to refrain from committing human rights violations, it is also an obligation to express their unconditional disapproval when private actors engage in acts of mistreatment. This

${ }^{45}$ See Philip Pettit, Republicanism: A Theory of Freedom and Government (1997). 
theoretical obligation is codified in legalistic provisions requiring that states "secure" the rights of the convention in practice.

There is a remaining question, which is why this communicative conception of punishment requires the imposition of harm upon the offender. What is to be gained by making the victim suffer and how exactly does that communicate anything to the victim, to the perpetrator, and to society at large? Indeed, the difference between a token punishment and a non-token punishment is that the former imposes no suffering on the offender while the latter imposes substantial suffering on him or her. Retributive theorists have proposed numerous answers to this question. Some have argued, for instance, that suffering allows the offender to engage in penance-a process that promises to return the offender into the moral community as a member in good standing. 46 The result in that situation is a form of "redemption" in the eyes of the community, a result that is only possible when the offender takes seriouslythrough his or her acceptance of their suffering-the moral wrongs they have inflicted on innocent parties. ${ }^{47}$ But a firmer conceptual ground is provided by teasing out the implications of an expressive theory of punishment. ${ }^{48}$ The punishment of the offender expresses not only society's condemnation of the behavior but also its solidarity with the victim, at least as regards to the particular criminal transaction in question (rather than blanket or wholesale solidarity). Although some form of expression is possible using other mechanisms - such as a legal declaration-only the perpetrator's suffering adequately communicates the profound moral devastation caused by the perpetrator's actions. Consider, for a moment, a community that refuses to punish a perpetrator but instead publishes a statement declaring that the perpetrator violated someone's rights in the most horrendous way possible. The perpetrator's impunity in that case communicates the community's lack of solidarity with the victim. It says, in other words, we care about your rights but we don't care about them enough to impose coercive measures on the individuals who violated your rights. If they do it again, we will issue another sentence, and they might do it again, and on and on. This result communicates society's commitment to impunity more than solidarity with the victim.

${ }^{46}$ See Christopher Bennett, The Apology Ritual: A Philosophical Theory of Punishment 118-19 (2010).

${ }^{47}$ See James Forman Jr., 'A Prison Sentence Ends. But the Stigma Doesn't', New York Times, 15 September 2017 ('Harvard's... [denial of admission to convicted murderer] reveals the truth about why mass punishment persists and the lie we are telling ourselves about the possibility of redemption.').

${ }^{48}$ See Drumbl (n 8) 174 ('The fact that consequences follow a guilty verdict makes law all the more real to the community.'). 
The obligation to express society's disapproval of the criminal offence, and to stand in solidarity with the victim, entails not just the exercise of punishment but also the correct amount of punishment. At this point, one might object that any amount of punishment, even a token punishment, could in theory express society's disapproval of the actions involved. Indeed, why should the amount of punishment matter at all? If the point is to communicate something, the "gesture" could be completed by any ministerial act without significant consequence for the perpetrator. A monetary fine would certainly be permissible. Or to borrow a line from contract law theory, perhaps depriving a perpetrator of a mere peppercorn would be enough to express social disapproval. ${ }^{49}$

But even a cursory inspection of actual cases shows why this is not possible in reality. Punishment via a token sentence almost always reveals a form of tacit encouragement, or at the very least moral equivocation. For example, why was Daschner given the token sentence? Yes, of course, the token punishment expressed society's disproval of the action, but the whole reason the court imposed the token fines was because it wished to communicate that Daschner's actions were not a typical case of torture. Indeed, the punishments in his case communicated tacit encouragement because that is precisely what motivated the district court's decision: They were not fully convinced that Daschner's behavior was truly as blameworthy as other cases of torture or police coercion. Consequently, disproportionately lenient punishment violates the same conceptual prohibition as not punishing a perpetrator at all because it fails to express society's disapproval of the action in question. ${ }^{50}$

Surely, though, a state should be permitted to dispense mercy, even in tough cases where the defendant has committed a grievous wrong. Some states refuse to punish offenders when the offender, though culpable, is severely old or ill. Sometimes parole boards release offenders after evidence of good conduct, expressions or remorse, or rehabilitation. Presidents, governors, or

${ }^{49}$ See E. Allan Farnsworth, Contracts $\S 2.11$, at 66 n. 2 (1982), quoting E. Coke on Littleton 222 (1628).

${ }^{50}$ See Mary Penrose, 'Lest We Fail: The Importance of Enforcement in International Criminal Law', 15 Am. U. Int'l L. Rev. 321, 383-86 (2000); Stuart Beresford, 'Unshackling the Paper Tiger: The Sentencing Practices of the ad hoc International Criminal Tribunals for the Former Yugoslavia and Rwanda', 1 Int'l Crim. L. Rev. 33, 90 (2001); Margaret M. DeGuzman, 'Harsh Justice for International Crimes?', 39 Yale J. Int'l L. 1, 33 (2014) ('An especially troubling critique may come not from retributivists but from expressivists. Proponents of the expressive function of international punishment may argue that mild or moderate punishment fails to express sufficient condemnation to promote the norms prohibiting international crimes.'). It should be noted that DeGuzman goes on to criticize that position. 


\section{The Right to Punishment}

heads-of-state issue pardons that exempt individuals from criminal responsibility-and punishment—for their crimes. In some circumstances, offenders are released on compassionate grounds- "compassion" for the offender, not the victims, incidentally. For example, Scottish officials released Abdelbaset alMegrahi on compassionate grounds in 2009, despite his conviction in 2001 for participation in the bombing of Pan Am Flight 103, which was destroyed over Scottish airspace in 1988, littering the bodies (and body parts) from the 243 passengers and 17 crew over miles of farmland. Although al-Megrahi had not yet completed his full sentence, he was released when it became apparent that he was suffering from prostate cancer and allegedly only had months to live. He returned to Libya where he was met with a hero's welcome as a figure of national significance-hardly a situation where the audience recognized his culpability for the harm that he caused. ${ }^{51}$ Despite the original diagnosis, he eventually survived for another three years, ultimately dying in 2012 . He lived his last three years in freedom. ${ }^{52}$

What these and other examples demonstrate is that "mercy" has a shadow side. It communicates the state's sympathy towards the plight of the defendant in the face of the coercive machinery of state punishment. The sympathy might be generated by a medical predicament, by the offender's virtuous conduct while incarcerated, or by a sense that the law was unkind to the offender by insisting on the strict application of criminal law provisions. But these expressions of sympathy are often a zero-sum game. By concluding that the offender should be exempt from punishment, the state is also, inevitably, saying something profound about the nature of the victimization of the case. Why? Because the state always has the option of forgoing mercy in some cases-cases of horrendous brutality where mercy is off the table. By agreeing that in some cases mercy remains on the table, the state is communicating something about its assessment of the conduct in the case. The only way around this conclusion is to think that the decision to dispense mercy is always solely based on considerations of the offender's predicament. But it rarely is. More typically, mercy decisions weigh considerations of the offender's predicament against the offender's blameworthiness for the criminal behavior. And that balancing process inevitably involves the state expressing a particular judgment on the significance of the original harm in the case.

Along the same lines, one might wonder whether the duty to punish is subject to balancing along with other state interests. In other words, should the state obligation to punish be absolute, or should it give way when the state has other interests that counsel in favor of mercy? Indeed, exercising mercy, or

51 John F. Burns, 'New Questions in Lockerbie Bomber's Release', New York Times, 21 August 2009.

52 Robert McFadden, 'Megrahi, Convicted in 1988 Lockerbie Bombing, Dies at 60', New York Times, 20 May 2012. 


\section{The Right to Punishment}

foregoing punishment entirely, may be necessary to advance a particular utilitarian goal. A state might have limited resources that it wishes to devote to policing and incarceration. Or the state might have empirical evidence that punishment will increase the likelihood of recidivism, rather than reduce it, at least with regards to certain situations or certain pockets of the population. ${ }^{53}$ Finally, to be cynical, state exercises of mercy may communicate a government's grace; the population may reward the government's exercise of mercy with renewed gratitude, loyalty, and fidelity to the government's rule. The push and pull of these competing interests may require the state to balance away the duty of punishment. Is this acceptable?

This question need not be answered here. Some rights, such as the right to human dignity, are inviolable and are recognized as such in many legal cultures. But let us assume that the right to punishment is one among many rights to which the state is a guardian. Even if ultimately balanced away, in favor of some exercise of mercy, it is important to recognize the moral interests of the victim and to express those interests in the language of human rights. Then and only then can the balancing proceed faithfully. In balancing, by definition, something is lost when something is gained, and it is important to articulate what is lost in the most forceful terms possible before it can be determined that society can and should live with the loss.

Some philosophers and legal theorists argue that mercy is normatively desirable and that the criminal justice system should be designed in such a way as to promote mercy wherever possible. For example, consider Martha Nussbaum's argument in favor of mercy:

In a sense, the merciful judge looks backward. But at the same time, while acknowledging the fact of wrongdoing, and thus expressing society's commitment to core values, the judge also looks forward to a world of reintegration. The general spirit is that of Transition-Anger: there is outrage at the wrong done, but a generous spirit takes the place of the punitive spirit. In addition to the usual concern about specific and general deterrence, and sometimes incapacitation, this judge also asks about how, in a world of human frailty, we may all be able to live

${ }^{53}$ See United States v. Luna-Jasso, No. CR 14-3523 JB, 2015 WL 1006390, at *15 (D.N.M. Feb. 19, 2015) ('The Court has previously noted that the certainty of being caught is a greater deterrence than the severity of the punishment and that incarceration increases recidivism rates.'). 


\section{The Right to Punishment}

together as well as possible. This concern may sometimes take the form of specific mercy to a specific defendant. ${ }^{54}$

Although Nussbaum goes on to concede that mercy should not lead to mitigation in every case, the overall tenor of her argument is in favor of mercy because she views punishment as a last resort. ${ }^{55}$ If society can protect the welfare of its citizens, in a forward-looking way, with non-penal sanctions, then criminal punishment is neither desirable not justifiable.

Nussbaum's pro-mercy view runs the risk of focusing more on the offender than the victim. Later, she concludes that the system should communicate that "the crime is outrageous, but we can see the offender, with sympathy, as someone who is more and better than the crime, capable of good in future, and we can adjust our sentencing in light of that thought." ${ }^{6} 6$ Then, Nussbaum suggests "we redouble our dedication to creating more propitious conditions for all." 57 The problem with this view is that the victim recedes into the background and the state's merciful response to the victimization seems calibrating to preventing future victims rather than responding to the past victimization, by the offender, of this particular human being whose rights and humanity were disrespected in some profound way.

For Nussbaum, mercy is the perfect antidote to anger, a negative emotion that she considers intimately and inevitably wrapped up with retributivism. For her, anger is best viewed as a negative emotion without redeeming qualities. The concepts of righteous indignation or noble anger are, at best, foolhardy notions; at worst, they are inherently contradictory, because anger is fatally corrosive rather than noble. But the field of international criminal law is an entire field built on noble anger-anger at the evil that men do and the fields that were littered with human beings who were treated like inanimate objects, disrespected and casually disposed like pieces of rotten flesh. That anger has spurred a generation of international lawyers, and civil society organizations, to insist that no one should be above the law or immune from criminal consequences. That was how the anti-impunity norm achieved its prominent place in our present global consciousness. International criminal law is the house that rage built.

\footnotetext{
${ }^{54}$ Martha Nussbaum, Anger and Forgiveness: Resentment, Generosity, Justice 207 (2016).

55 Id.

${ }^{56}$ Id. at 207-208.

${ }^{57}$ Id. at 208.
} 


\section{The Right to Punishment}

The anti-punishment "consensus" that dominated South Africa's Truth and Reconciliation process is the exception that proves the rule, not a framework for future justice in all places. ${ }^{58}$ The perpetrators who went unpunished in that process earned (or were bestowed) a form of impunity that certainly ran afoul of the basic normative prescription underlying the Gäfgen decision. While horrendous crimes of state were left unpunished, quotidian crimes committed by ordinary citizens in their daily lives yielded imprisonment, and continue to do so to this day. One wonders what message this result sent to the perpetrators, to the victims, and to the world. It is almost never the case that mercy and forbearance are handed out universally or evenly. Decisions about which cases deserve mercy and which ones do not invariably camouflage implicit judgments about which crimes are taken more seriously than others.

The view that we have sketched out in this section might best be described as a form of expressive retributivism, in keeping with a line of quasiretributivist accounts of punishment articulated by, among others, Antony Duff. ${ }^{59}$ I have defended a particular version of expressive retributivism that requires coercive punishment imposed against offenders. ${ }^{60}$ In the absence of that punishment, society expresses the sentiment that the perpetrator enjoys impunity for his or her actions. ${ }^{61}$ Conversely, when the offender is punished, the community expresses its conviction that impunity is intolerable and expresses its solidarity with the victims. This anti-impunity version of expressive

${ }^{58}$ See id. at 211 et seq.

${ }^{59}$ See R.A. Duff, Trials and Punishments 233-66 (1986); Joel Feinberg, 'The Expressive Function of Punishment', 49 Monist 397 (1965). For a critique of expressivism, see Matthew D. Adler, 'Expressive Theories of Law: A Skeptical Overview', 148 U. Pa. L. Rev. 1363, 1369 (2000).

${ }^{60}$ See also Dan Markel, 'Are Shaming Punishments Beautifully Retributive? Retributivism and the Implications for the Alternative Sanctions Debate', 54 Vand. L. Rev. 2157, 2189 (2001) (discussing theory of 'confrontational retributivism'); Dan Markel, 'What Might Retributive Justice Be? An Argument for the Confrontational Conception of Retributivism', in Retributivism: Essays on Theory and Policy 49, 58-59 (Mark D. White ed., 2011).

61 If forced to describe my theory of punishment, I would describe it as the "anti-impunity conception of expressive retributivism." Although theorists of punishment have never explicitly identified and defended such a variant of expressive retributivism, I think it articulates a widely-shared intuition among international criminal lawyers and human rights activists. However, differences emerge when you ask lawyers why expressing anti-impunity is important. A few will argue that expressing anti-impunity is important to deter future crime, whereas I (and others) would assert that expressing anti-impunity has intrinsic rather than instrumental moral value. 
retributivism owes much to the anti-impunity discourse at the heart of international criminal law. ${ }^{62}$ In this sense, international criminal law has much to teach domestic criminal law, in the sense that theorists of domestic criminal punishment should bring the anti-impunity norm "home" to justify punishment in their municipal systems. It is somewhat odd that the anti-impunity rhetoric has mostly been limited to the international context.

\section{IMPLICATIONS FOR INTERNATIONAL CRIMINAL LAW}

The first question for the international criminal lawyer is whether the right to punishment outlined above is a creature of European human rights law or whether it is embodied in international human rights law as well. Although there are no international decisions articulating the right in the same language at the international level, this is only because there are fewer fora for adjudicating international human rights when compared with their European analogs. Consequently, one must scrutinize the underlying rights to see if they are uniquely European or whether they are both European and international at the same time (as many rights are).

First, the right to be free from torture and other forms of mistreatment is codified in international instruments, notably the Convention Against Torture but also article 7 of the ICCPR which prohibits both torture and cruel and degrading treatment. Second, the right to life is also protected not just by European law but also article 6 of the ICCPR which states that "Every human being has the inherent right to life. This right shall be protected by law. No one shall be arbitrarily deprived of his life." Third, even in cases where death does not occur, victims have a right to "liberty and security of person" under article 9 of the ICCPR and a right to respectful treatment consistent with their "inherent dignity" according to article 10.

Fourth, and finally, the state obligation to provide a remedy is not a European-only right. It is clearly international and codified in the ICCPR in at least two places. As noted above, article 6 requires that the right to life be protected by law, which arguably, although implicitly, might refer to the need for an adequate remedy. But more importantly, article 2 of the ICCPR requires that states "ensure to all individuals within its territory and subject to its jurisdiction the rights recognized in the present Covenant..." This provision is controversial because its interpretation implicates the question of the extraterritorial scope of the Convention. But putting aside that controversy, which is not relevant here, it is undeniable that article 2 imposes not only a negative

${ }^{62}$ See, e.g., Ronen Bergman, 'Why Did Israel Let Mengele Go?', New York Times (6 September 2017) ('The capture and trial of Eichmann — and his execution—were enough to teach the world about the Holocaust and to convey to the message that Jewish blood cannot be spilled with impunity'.). 
duty that a state refrain from violating human rights, but also imposes a positive obligation to take actions necessary to "ensure" the rights in the Convention. Just as the European Convention requires that states take action to "secure" the convention's rights, so too the ICCPR requires that states take actions to "ensure" the rights in the international convention. In both cases, there is a strong argument that the positive duty entails the imposition of appropriate and proportionate criminal penalties on perpetrators who violate the rights of human beings whose inherent dignity is protected by the law. The structural argument is the same in both contexts.

Consequently, international criminal lawyers should recognize that the right to punishment is a human right enjoyed by victims of particularly grave international crimes. Doing so would dovetail with the existing anti-impunity foundation for international criminal law, adding content to its otherwise indeterminate edges, and would also have practical consequences for the practice of international institutions.

The anti-impunity norm is recognized in the preamble of the Rome Statute, which articulates, inter alia, the following normative commitments:

Affirming that the most serious crimes of concern to the international community as a whole must not go unpunished and that their effective prosecution must be ensured by taking measures at the national level and by enhancing international cooperation... Determined to put an end to impunity for the perpetrators of these crimes and thus to contribute to the prevention of such crimes... Recalling that it is the duty of every State to exercise its criminal jurisdiction over those responsible for international crimes... ${ }^{63}$

Each of these clauses reaffirms that a core purpose of international criminal law is to prosecute and punish individuals who would otherwise escape punishment for international crimes.

The logic of the anti-impunity norm is brought to fruition with the principle of complementarity. The ICC only has jurisdiction over situations and crimes that are not adequately investigated and prosecuted by domestic jurisdictions. Where there is no sincere or credible domestic prosecution, the ICC gains the jurisdiction necessary to close that impunity gap. But if a domestic jurisdiction is able and willing to prosecute the offenders, there is no impunity gap to be filled and the ICC's putative jurisdiction evaporates. ${ }^{64}$

${ }^{63}$ International Criminal Court, Rome Statute, preamble, U.N. Doc. A/CONF.183/9 (1999).

${ }^{64} \mathrm{Id}$., art. 17. 
For these reasons, the human right to punishment should be of particular concern for international institutions working to fulfill this anti-impunity goal. Indeed, in the first clause of the preamble quoted above, the existence of a judicial process is itself insufficient to satisfy the anti-impunity goal; international cooperation is required to ensure that "serious crimes of concern... must not go unpunished." Indeed, if a state prosecutes an offender or offenders but then grants a blanket pardon to all involved, or even introduces a token punishment a la Daschner, then the anti-impunity norm is notfulfilled.

Some scholars have already cashed out the complementarity principle in punishment terms. For example, Kevin Jon Heller has argued that a state prosecution satisfies the complementarity principle if the defendant is subject to criminal punishment that equates with the punishment that the defendant would receive in an international forum, i.e. at the ICC. ${ }^{65}$ If the defendant faces a lesser punishment at home then he would at The Hague, the complementarity principle is not satisfied and the ICC should retain jurisdiction. Or so says Heller. ${ }^{66}$ Without taking a stand on Heller's interpretation of the complementarity principle, it is sufficient to note that some scholars have already explicitly linked the duty to punish with the court's jurisdiction. The duty to punish, whether in a state's system of criminal justice or at an international institution, is already codified in the Rome Statute. What I have tried to show in this essay is that the Rome Statute's recognition of the duty to punish did not materialize out of thin air. Many observers have assumed that states constructed the ICC out of a sense of beneficence-a simple desire to make the world a better place. However, the account sketched out in the present essay suggests that the creation of the ICC (and other international institutions) was legally obligatory. If indeed victims have a fundamental right to see their tormenters punished, and this right is embodied in international human rights law, then creating a system of justice based on the anti-impunity norm was required by international law, not simply permitted by it. In other words, states constructed the Rome Statute and the ICC as a way of fulfilling their obligations to punish under international human rights law.

The question arises what consequences, if any, the human right to punishment might have for the actual operation of international criminal justice. For starters, both the ICTY and the ICC include provisions allowing for early release before the completion of a sentence. These procedures should be pursued delicately because their implementation might infringe the human right to punishment. If a defendant is convicted of a crime against humanity but is released after only serving, say, five years of a 30-year sentence, there is a

${ }^{65}$ Kevin Jon Heller, 'A Sentence-Based Theory of Complementarity', 53 Harv. Int'l L.J. 85, 131 (2012).

${ }^{66}$ Id. at 87. 
strong argument that the commutation is an impermissible example of tokenism. For example, article 110 of the Rome Statute contemplates that the Court may reduce, at any time, the sentence of a convicted person. Furthermore, article 110(3) stipulates that all defendants shall be entitled to a hearing regarding reduction in sentence once they have served 25 years in prison or twothirds of their sentence, whichever comes first. The criteria that the court is directed to consider include: (a) the defendant's willingness to cooperate; (b) the defendant's assistance with forfeiture and reparations; and (c) a change in circumstances that would justify the sentence reduction. Presumably, a change in circumstances regarding the defendant's acceptance of blame, rehabilitation, or mental or physical health might satisfy the "change in circumstance" criteria.

Noticeably absent from the article 110 criteria is any mention of the gravity of the offense or the impact on the right of the victims to see their perpetrators adequately punished and whether releasing the defendant will compromise that right. In this regard, the ICTY Rules of Procedure and Evidence are far superior, because Rule 125 of the ICTY RPE offers the following guidelines for the President's consideration of pardons and commutations: "In determining whether pardon or commutation is appropriate, the President shall take into account, inter alia, the gravity of the crime or crimes for which the prisoner was convicted, the treatment of similarly-situated prisoners, the prisoner's demonstration of rehabilitation, as well as any substantial cooperation of the prisoner with the Prosecutor" (emphasis added). The Rome Statute provision should be amended to require it to take into account the same criteria. However, despite the inclusion of this rigorous standard in the ICTY RPE, the RPE is deficient in that it allows the Court's President, rather than the full court, to make this determination. This provision allows the president to effectively unwind a sentencing determination made by a full panel of judges who sat through a trial or appellate proceeding, with information that the president may not have fully absorbed or appreciated. The ideal scenario would be a provision that combines the correct standard from the ICTY RPE with the Rome Statute's procedural requirement that the sentence reduction come from the full court rather than one individual alone.

This raises a last question: Are international tribunals bound by international human rights law? Under a restrictive and highly formalist reading of human rights law, only states are bound to follow its requirements. An international tribunal is not a state, and even though individual judges come from particular states, their judicial decisions are not acts of state but are, rather, actions of an international tribunal. If this view is correct, it suggests that international tribunals are not bound by the human rights conception I have outlined here, either in its initial sentencing decision or in a petition for a pardon or sentence reduction. Are international tribunals unconstrained in this manner? 
There are two important answers to this objection. The first is that international tribunals make frequent references to international human rights law, both in terms of provisions violated by perpetrators but also in terms of procedural protections for defendants. It is widely assumed by judges that defendants are owed a fair process, not just by virtue of the provisions in the Rules of Procedure and Evidence, but also by virtue of their human rights, which codify that all individuals have a right to a fair judicial process. ${ }^{67} \mathrm{Of}$ course, the human right to a fair process goes to the benefit of the defendant, while the human right to punishment runs to the detriment of the defendant because it counsels in favor of punishing the guilty. But these two aspects of human rights law are conceptually linked; international tribunals are bound to apply the law and that law extends beyond the four corners of the Rome Statute or whatever constitutive document governs the creation of the tribunal.

Furthermore, even if we were to concede that states are the ones bound by international human rights law, states have created these tribunals, either directly through treaty in the case of the ICC or indirectly through international institutions such as the United Nations Security Council (in the context of the ICTY and ICTR). In that case, states may bear an indirect responsibility under international human rights law to create international institutions that respect the human right to punishment. In Gäfgen, the right in question required that the state conduct its criminal process in a manner consistent with this human right. In the international context, the right entails that states have an obligation to create international institutions with procedures and standards in place that will respect the rights of victims to an adequate criminal remedy. If states create international institutions that flagrantly violate that right because of a structural problem in the standards articulated in their statutes, then indirectly states may be responsible under human rights law for violating the right to punishment. Admittedly, this argument cuts against the current trend regarding the responsibility of international organizations, though perhaps international law is evolving in a direction where it can appreciate that states may be responsible, in some derivative way, for the acts of the international institutions that they create. Someday, international law may "pierce the veil" of international institutions. Even before then, though, international tribunals already consider international human rights law as a valid source of law for them to apply in their decisions.

\section{CONCLUSION}

This chapter has defended a particular conception of punishment grounded in the human rights of victims; specifically, the right of victims that

${ }^{67}$ See, e.g., Milosevic (n 11) para. 29. 
generates a corresponding duty on the part of the state to punish wrongdoers responsible for the original victimization. The chapter started with an analysis of the Gäfgen case, which articulated the existence of this right in cases of torture and other forms of mistreatment. Then, following that logic to its ultimate conclusion, this chapter suggest that the same arguments apply, mutatis mutandis, to all international crimes. In cases of genocide, crimes against humanity, and war crimes- the punishment of the perpetrators is not just legally permitted; it is legally required. This subtle change in emphasis-moving from punishment as a license to punishment as a legal requirement-has profound consequences for the operation of international criminal justice. States and international tribunals are required to punish perpetrators as a matter of human rights law, and their failure to follow through on this obligation violates not just some vague or inchoate ergo omnes obligation, it also violates an obligation owed directly to the victims of that particular atrocity.

Recognizing this fact will augment the role and significance of victims in international criminal procedure. Regardless of whether victims are formal participants of the criminal process as partie civile, victims are legal stakeholders in the outcome of the criminal process, i.e. the punishments that are handed down to vindicate their human rights. Finally, acts of mercy or compassion, such as sentence reductions in the form of pardons, commutations, and compassionate release for health reasons, potentially infringe the right to punishment. Although acts of mercy are not necessarily illegal, at the very least, acts of mercy must take into consideration the interests of the victims in the execution of the criminal sanction to prevent cases of excessive mercy from opening a back-door to impunity.

The argument in this chapter could also, in theory, be extended to domestic penal offences as well. Although this is beyond the scope of this chapter, one could argue that victims have a right to see their perpetrators punished for all crimes that rise in seriousness above a certain threshold-say offences that implicate the security of the person at a fundamental level. This would capture cases of domestic murder and rape that are illegal under domestic law but which states are not under an obligation to penalize in the sense in which they are obligated to punish genocide and torture by virtue of international agreements. However, if the argument in this chapter is correct, the human right to punishment is larger than international crimes, since the relevant provisions in the ICCPR and the ECHR make no mention of war crimes, crimes against humanity, and genocide. A victim's right to punishment-with the corollary obligation not to bestow excessive mercy-would apply to state actors engaged in the quotidian work of the domestic criminal lawyer. Although this application of the thesis was not defended in this chapter, the logic of its argument is strongly suggestive of an affirmative conclusion. At the very least, this presents an intriguing avenue of future research for domestic criminal law theory. 